УДК 631.358:635.6

(C) О.В. Шовкомуд, к.т.н., В.Л. Мартинюк, к.т.н.

Луцький національний технічний університет

Гунчик Р.В.

Любешівський технічний коледж Луцького національного технічного університету

\title{
АНАЛІЗ ТЕХНОЛОГІЙ ТА ТЕХНІЧНИХ ЗАСОБІВ ЗБИРАННЯ ГАРБУЗІВ
}

У статті розглянуто значення сільськогосподарської культури - гарбуз та можливі сфери використання його плодів. Викладено результати аналізу технологій збирання гарбуза та технічних засобів для ї̈ здійснення. Виконаний аналіз має за мету виявити недоліки чинних механічних засобів для збирання гарбуза, особливо плодів, призначених для продовольчих иілей.

Постановка проблеми. Зростання кількості вирощуваних овочів на сьогодні $\epsilon$ актуальною проблемою. Це обумовлено збільшенням чисельності населення планети і веде, відповідно, до зростання споживання всіх продуктів харчування, зокрема й овочів. Одним 3 корисних і смачних овочів $\epsilon$ гарбузи, але вони на сьогоднішній день не користуються великим попитом. Гарбуз може довго зберігатися i тому можна продовжити термін його споживання. Ця властивість використовується при вирішенні питання про безперебійне постачання овочами населення.

Вирощуванням гарбуза на Рівненщині займались сільськогосподарські підприємства, розташовані у чотирьох районах області. У 2012-2013 роках у Корецькому, Здолбунівському, Острожському та Дубенському районах олійними гарбузами засівали більше трьох тисяч гектарів. Більше 600 тонн якісного голозерного насіння 3 Рівненщини поставлено на переробку в Австрію. Місцеві сільгосппідприємства, які $\epsilon$ партнерами австрійської кампанії, мали гарантований ринок збуту насіння, стабільний прибуток і безкоштовне органічне добриво, яке залишалось на полях. Більше того, іноземці були зацікавлені саме в рівненській продукції, оскільки наші грунти роками не обтяжували важкими міндобривами, тому й сировина для переробки чиста та якісна.

Насіння австрійці використовують у фармакології, кондитерській промисловості, для хлібопечення, основну ж масу переробляють на олію. Відтак, перевиробництво іноземців не лякає, 
а навпаки - вони зацікавлені в якісній сировині та збільшенні посівних площ.

У Рівненській області на даний час відроджують виробництво гарбуза. У 2019 році компанія ТОВ «ФаворитАгро» - високотехнологічне сільськогосподарське підприємствовиробник, яке було створено в 2005 році в м. Корець Рівненської області, планує засіяти тисячі гектар даною культурою після багаторічної перерви.

Гарбуз має високе харчове та кормове значення та може споживатись як натуральний продукт без додаткової обробки так і у вигляді продукту переробної галузі.

Вміст у плодах гарбуза вітамінів A, E, C, B , B $_{2}, \mathrm{~B}_{5}, \mathrm{~B}_{6}, \mathrm{PP}$ i рідких Т і К робить його дуже потрібним для організму людини. Плоди гарбуза містять таку кількість білка, що спів ставна з вмістом у м'ясі.

Плоди гарбуза рекомендовані також до застосування тваринам, зокрема для молочних корів. Їх застосування сприяє підвищенню надоїв i вмісту жиру в молоці [1]. Відходи виробництва олії насіння гарбуза використовують для медичних цілей.

Гарбуз одна з найбільш урожайних і рентабельних культур, урожайність якої сягає 50-70 ц/га.

В Україні вирощують три види гарбуза - твердокорий, крупноплідний та мускатний.

За даними Державного статистичного управління [2] у 2018 році Україні посівні площі під гарбузами зросли майже в два рази (у порівнянні з 2017 роком) і становили 1 тис. га.

Сучасний розвиток сільського господарства вимагає вирішення цілої низки задач, серед яких зростання товарного виходу продукції 3 високими якісними показниками за умови значного зменшення або повного виключення ручної праці як у процесі збирання культури так і вході їі переробки.

Збирання плодів гарбуза є затратною операцією. За літературними даними під час вирощування гарбуза на збирання припадає до 40\% всіх витрат [3].

Засоби механізованого збирання даної культури низькопродуктивні та потребують подальшого розвитку.

Слід також зауважити, що переробка такої культури, як гарбуз не дозволяє повністю виключити ручну працю. Це пов'язано 3 властивостями не лише самої рослини, а й плодів. Відомі технології збирання та переробки гарбуза містять операції, які виконуються лише вручну. 
3 урахуванням вище зазначеного, задача розробки технічних засобів, які будуть спрямовані на підвищення продуктивності процесів збирання та первинної переробки гарбуза, $\epsilon$ актуальною та потребує вирішення.

Аналіз останніх досліджень і публікацій. Дослідженню процесу збирання баштанових культур присвячено роботи Аббасова 3. [4], Абезіна В. Г. [5], Белоконя В.Н., Чабана Л.Н. [6], Бормотова А.Л. [7], Листопада Г.Е. [8], Цепляєва В.А. [9] та інших.

Аббасовим 3. досліджено процес вибіркового збирання плодів баштанових культур за допомогою універсальної платформи. 3 урахуванням глибокого аналізу чинних способів збирання плодів баштанних культур Абезіним В. Г. розроблено агрегат для механізованого збирання баштанних i конструкції машин, які забезпечують часткову механізацію вибіркового збирання за допомогою широкозахватних транспортерів. Застосування запропонованого агрегату дозволило підвищити продуктивність виконання збиральних робіт у $3 \ldots 4$ рази.

Розробці технології та технічних засобів, які забезпечують зменшення ручної праці, підвищення ефективності підбору та завантаження гарбузів у транспортні засоби присвячено дослідження Бормотова О.Л. Автором розроблено технологічні схеми збирально-транспортних комплексів. Запровадження підбирача для підйому та вивантаження у транспортний засіб плодів гарбуза різних сортів дозволяє фіксувати положення плодів і підвищити якість виконання процесу. Застосування підбирача також дозволило зменшити витрати праці на збиранні гарбузів на $32,2 \%$, підвищити продуктивність збирання в 1,2 рази.

Цепляєв В.А. запропонував та дослідив валкоутворювач плодів баштанових культур некруглої форми. Запропонована автором конструкція відповідає агротехнічним вимогам, що пред'являються до машин для збирання баштанових культур. Основними з цих вимог, за твердженням автора, є продуктивність та зменшення травмування плодів.

Аналіз відомих досліджень виявив, що технічні засоби для збирання гарбузів не задовольняють в повній мірі агротехнічні вимоги, характеризуються складністю та високою вартістю. Тому обгрунтування напрямків удосконалення технології збирання гарбузів із розробка технічних засобів, які забезпечать високу продуктивність процесу збирання та унеможливлять травмування плодів $\epsilon$ актуальною задачею. Підгрунтям для вирішення даної задачі $\epsilon$ аналіз відомих технічних засобів і технологій збирання гарбузів. 
Мета дослідження. Проаналізувати існуючі технології та технічні засоби для збирання гарбузів.

Результати дослідження. Висока врожайність і невибагливість гарбуза, а також високий попит роблять цю культуру привабливою як для великих сільськогосподарських підприємств так й для малих фермерських господарств.

Збирання гарбуза починають тоді, коли плоди набувають жовтого кольору 3 переходом у коричневий. Ботва може залишатись зеленою, але набуває світло-жовтого окрасу.

Вибір комплексу машин для збирання гарбузів залежить від обраної технології, яка визначається метою використання плодів. Відомими є три напрямки використання плодів: на технічні цілі, на насіння та для комплексної переробки.

Гарбузи збирають, в основному, на насіння. Для здійснення технології збору гарбуза на насіння використовують валкоутворювачі, які скочують ягоду у валки, а після цього до роботи приступають комбайни. Валкоутворювачі (рис. 1) складаються 3 передньої та задньої навісок 1 і 5. На несучих брусах навісок розташовані секції 4 з опорними колесами 3 та планки для зсуву плодів.

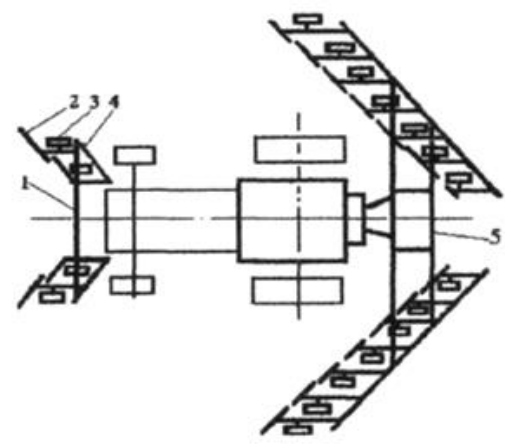

$a$

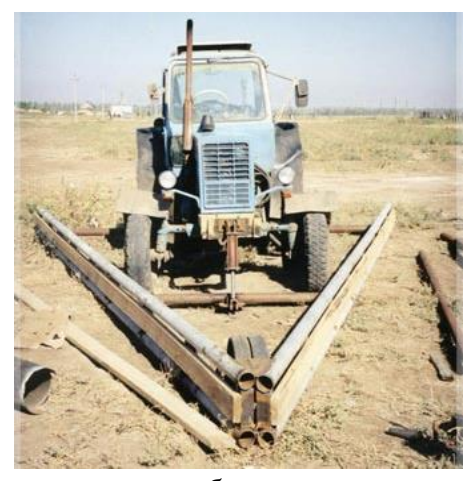

б

Рис. 1 - Валкоутворювач: $a$ - схема:1-навіска, 2- планки, 3- опорні колеса, 4-секції, 5-навіска, $\sigma$ - фото

За один прохід валкоутворювач скочує у валок плоди 3 полоси шириною 8 м. Втрати плодів на скочування становлять до $2 \%$, пошкодженість плодів до $7 \%$.

Значно зменшити пошкодженість плодів та забезпечити утворення насичених валків дозволяє застосування 
валкоутворювача австрійської фірми-виробника техніки для збирання гарбузів МОТY (рис. 2). Валкоутворювач оснащено двома валами. Один вал на гідравлічному приводі, другий вал тримає ботву гарбуза, притискає ії̈ до поверхні поля.

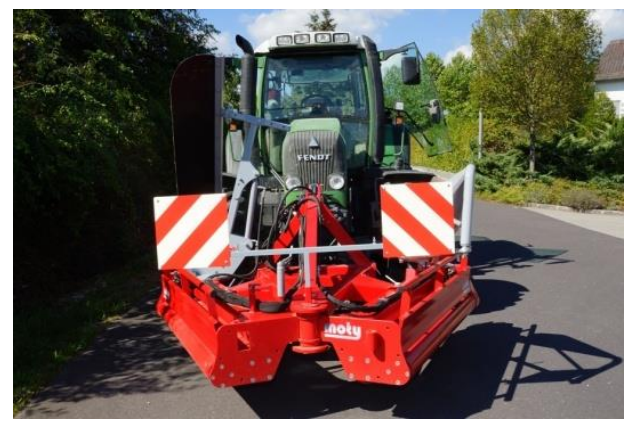

Рис. 2 - Валкоутворювач гарбузів МОТY

Після збирання в валки плоди підбирає комбайн і вибирає насіння гарбуза, а м'якоть залишають в полі. Продуктивність комбайна в середньому - 5 га в зміну.

В Україні Каховським механічним заводом розроблено комбайн для збирання гарбуза на насіння серии V-VD (рис. 3). Комбайн агрегатується 3 трактором типу МТ3-82.. Комбайн складається 3 рами, на якій змонтовані металевий барабан 3 штирями для наколювання плодів, подрібнювача і протирального барабана.

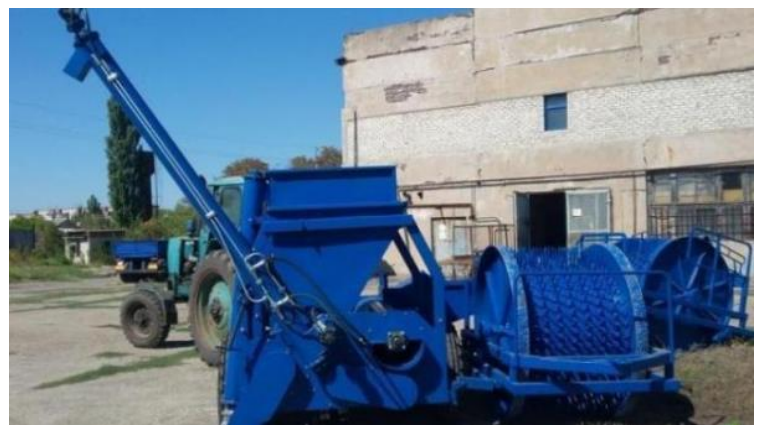

Рис. 3 - Український комбайн для збирання гарбуза на насіння V-VD 
Агрегат встановлюють так, щоб барабан зі штирями знаходився в зоні ряду плодів. При переміщенні агрегату вздовж ряду плоди наколюють на штирі барабана і переміщаються в подрібнювач. Продуктивність комбайна - 15 т плодів на годину. Кількість плодів з невибраними насінням гарбуза залежить від якості валка. При рівному укладанні плодів в валки обмолот комбайном (без ручного коректування) стовідсотковий.

Серед закордонних виробників комбайнів для збирання гарбуза на насіння слід відмітити Туреччину (комбайни TR 3001 ), Росію, Австрію (фірми Moty i Kropfel) (рис. 4, 5, 6).

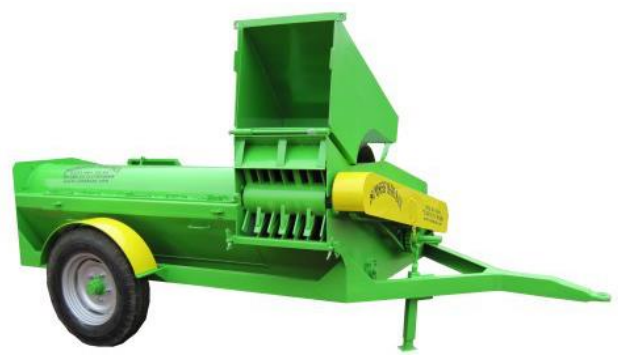

Рис. 4 - Комбайн для збирання гарбуза на насіння TR 3001

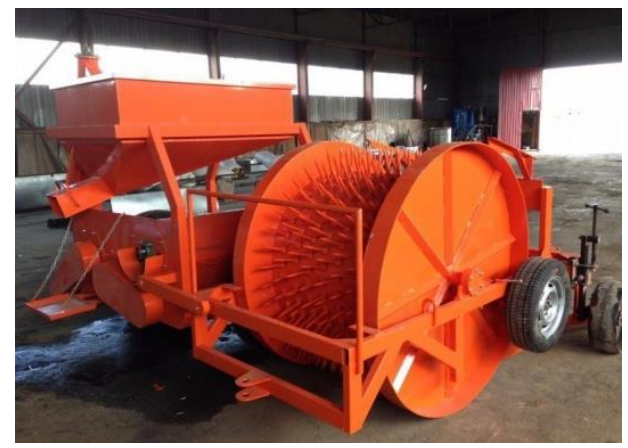

Рис. 5 - Комбайн для збирання гарбузів ТУК - 16 


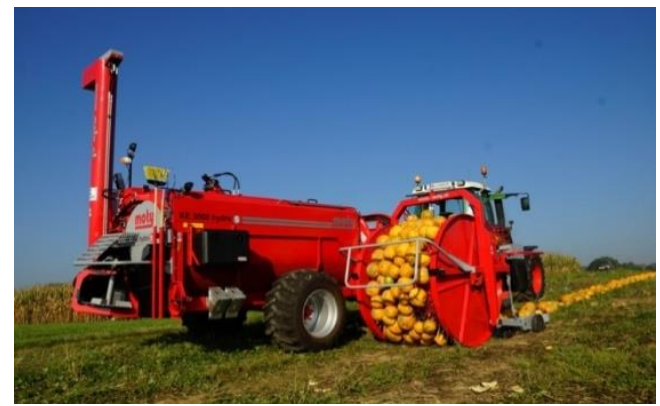

Рис. 6 - Комбайн КЕ 3000 М для збирання гарбуза на насіння фірми Moty

Комбайни фірми Moty відрізняються високою якістю збирання та мінімальними втратами насіння. Також слід відмітити незначні витрати часу для технічного обслуговування та очищення комбайна.

Як вітчизняна так і імпортна техніка для збирання гарбуза працює за одним принципом. На поле дозрілий гарбуз укладається в валки, агрегат проїжджає над ними, і гарбуза нанизуються на голки збирального барабана. Барабан передає плоди в завантажувальний бункер, звідки вони потрапляють до бичового барабану. Подрібнений гарбуз проходить через лопаті, які направляють насіння до шнеку, а м'якоть викидається на грунт. Насіння рухаються через решета, остаточно очищаються від м'якоті i насипаються в тару.

Австрійські комбайни для збирання гарбуза виконують ще один важливий процес - сушку насіння. Вологе насіння транспортуються в бункер по гнучкому рукаву, в який за допомогою вентилятора нагнітається гаряче повітря. М'якоть, яка викидається на поле, збирають та використовують для корму тваринам або заробляють у грунт у якості добрива.

За умови переробки гарбуза на продовольчі цілі, потрібно зібрати плоди неушкодженими з метою їхньої подальшої переробки на стаціонарних лініях. Технічні засоби для збирання неушкоджених плодів $є$ недостатньою мірою розроблені. Машини не отримали широкого застосування через конструктивнотехнологічні недоліки, зокрема низьку продуктивність і високий показник пошкодженості плодів.

На першому етапі збиральних робіт гарбуз, як i в попередньому випадку, групують у валки. 3 валків плоди збирають 
підбирачами, наприклад підбирачем вітчизняного виробництва V-VB.002 (рис. 7).

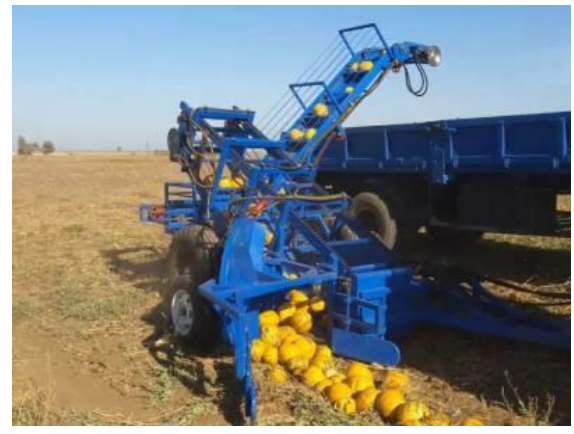

Рис. 7 - Підбирач для гарбузів V-VB.002 (Україна)

Взаємодія плодів із робочими органами підбирача веде до їхнього травмування, що обумовлено ударами плодів.

3 метою зменшення пошкодження плодів Шапровим М.Н. та ін. [10] запропоновано до використання роторний підбирач (рис. 8).

Роторний підбирач плодів баштанних культур не вимагає попереднього валкоутворення, що забезпечує зниження трудомісткості і підвищення продуктивності збирання баштанних культур 3 мінімальними пошкодженнями плодів. За даними польових випробувань роторного підбирача [10], його використання дозволяє механізувати збирання плодів баштанних культур на продовольчі цілі в стислі агротехнічні терміни зі зменшенням травмування плодів до $1 \%$, а також не вимагає попереднього валкоутворення, що забезпечує зниження трудомісткості на 20\%, збільшення терміну зберігання плодів і підвищення продуктивності збирання баштанних культур на 20\%, а також скорочення людей, зайнятих на зборі плодів. 


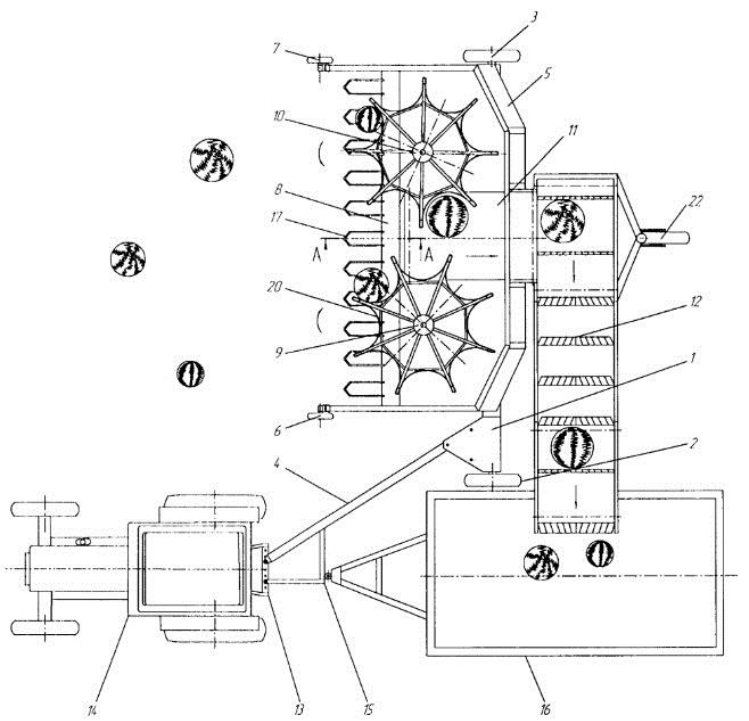

Рис. 8 - Роторний підбирач плодів баштанних культур: 1-рама, 2,3 - опорні колеса, 4 - причіпна спиця, 5 - платформа, 6,7 - копіюючі колеса, 8 - направляюча, 9, 10 - збиральні ротори, 11 - поздовжній транспортер, 12 - завантажуючий транспортер, 13 - навісна рама, 14 - трактор, 15 - додатковий причіпний пристрій, 16 - причіп, 17 - копіюючий елемент, 18 - упор, 19 - лоток, 20 - плодоприймальне вічко

Відомими є також підбирачі плодів гарбуза $[11,12]$, але жоден з них не отримав промислової реалізації.

Висновки. Аналіз чинних конструкцій машин, призначених для збирання гарбузів за різними технологіями дозволив встановити, що найбільшого розвитку отримали засоби для виконання технологій збирання гарбуза на насіння.

Конструкції машин для здійснення технології переробки гарбуза на продовольчі цілі, що потребує зібрати плоди неушкодженими 3 метою їхньої подальшої переробки на стаціонарних лініях, не знайшли широкого застосування через недоліки технологічного та конструктивного характеру. Основні 3 них - низька продуктивність i невідповідність агротехнічним вимогам за показником пошкодженості плодів. 


\section{Література}

1. Велик В.Ф. Бахчевые культуры/ В.Ф. Велик, М.: Колос, 1975, - $267 \mathrm{c}$.

2. Сільське господарство України:Статистичний збірник/Державна служба статистики України, 2018. - 245 с.

3. Абезин В.Г. Ресурсосберегающая почвозащитная технология механизированного возделывания и уборки бахчевых культур:учебное пособие/ В.Г. Абезин, Элиста, 1993. - С. 68-87.

4. Аббасов 3. Механизация возделывания бахчевых/ 3. Аббасов // Картофель и овощи, 1975 № 9,- С.31-32.

5. Абезин В.Г. Механизация возделывания бахчевых // Картофель и овощи. 1977. - № 5. - С. 44 - 45.

6. Белоконь В.Н. Пути механизации возделывания бахчевых культур/ В.Н. Белоконь, Л.Н. Чабан., В.Г. Абезин //Картофель и овощи, 1975 , №1 1,-с.33-34.

7. Бормотов А.Л. Совершенствование технологии и технических средств уборки тыквы подборщиком защемляющего типа. Дисс. канд. техн. наук. 05.20. Волгоград, 2005. - 150 с.

8. Листопад Г.Е. Состояние w перспективы развития'механизации^ возделывания, уборки и переработки бахчевых культур / Г.Е. Листопад, А.Н. Цепляев. // Научнотехнический прогресс в инженерной сфере АПК России. - М., 1995. - C.155-160.

9. Цепляев А.Н., Ульянов М.В., Ульянов А.В. и др. Результаты экспериментальных исследований валкообразователя активного типа // Известия Нижневолжского агроуниверситетского комплекса: наука и высшее профессиональное образование (Волгоград). 2010. № 3 (19). С. 188-192.

10. Патент.0002638652. Россия. МПК A01D51/00. Роторный подборщик плодов бахчевых культур с копирующим направителем плодов № 2643725. Шапиров М.Н., Седов А.В., Гурба А.В., Седова О.П. заявитель и патентообладатель ФГБОУ ВО «Волгоградский государственный аграрный университет»; заявл. 10.01.201 ;опубл. 15.12.2017.

11. Патент. 0002520126. Россия. МПК A01D51/00. Роторный подборщик плодов бахчевых культур № 2520126. Шапиров М.Н., Седов А.В., Цепляев А.Н., Рябухина О.П., Попов Е.А. Гурба А.В., Седова О.П. заявитель и патентообладатель ФГБОУ ВО «Волгоградский государственный аграрный университет»; заявл. 10.12.2013;опубл. 20.06.2014.

12. Пат. 2643725 РФ. МПК A01D51/00. Роторный подборщик плодов бахчевых культур с дисковым ножом / Шапров М.Н., 
Седов А.В., Седова О.П., Гурба А.В.; заявитель и патентообладатель ФГБОУ ВО «Волгоградский государственный аграрный университет»; заявл. 12.04.2017; опубл. 05.02.2018. 